\title{
CONTRATOS DE BOCA: a institucionalização da precariedade na construção civil ${ }^{1}$
}

\author{
Fernanda Flávia Cockell \\ Daniel Perticarrar ${ }^{* *}$
}

\begin{abstract}
Este artigo analisa a percepção de operários da construção de edificações sobre o contexto de vulnerabilidade social, marcado pela precarizacão crescente dos contratos de trabalho. Foram entrevistados vinte trabalhadores da cidade de São Carlos (Brasil), recuperando suas trajetórias de trabalho. Por meio da análise qualitativa das entrevistas, foi possível verificar a vulnerabilidade e as formas variadas de contratos de trabalho e de remuneração. Apesar da precariedade das relações de trabalho, metade dos trabalhadores afirma estar realizada profissionalmente na ocupação desempenhada, enquanto a outra metade se percebe diminuída perante a sociedade pela falta de estudo, ou se identifica com as outras profissões exercidas anteriormente, vendo a construção como uma etapa passageira ou como a ultima opção que lhes restou.

PALAVRAS-CHAvE: Trabalho flexível, vulnerabilidade, contratos de trabalho, percepção operária, construção de edificações.
\end{abstract}

\section{INTRODUÇÃO}

O trabalho na construção de edificações é caracterizado por informalidade, provisoriedade, grande contingente de trabalhadores informais, terceirizados ou subcontratados, alta rotatividade, alto grau de flexibilidade em termos de recursos humanos e constante processo adaptativo a novas realidades de trabalho e de vida. É a

expressão paradigmática da sociedade da insegurança, entre cujas características se encontram: a fragilidade dos arranjos laborais, a instabilidade ocupacional, o subemprego, o desemprego recorrente, duradouro e sem perspectiva de inserção no mercado formal. (Mangas, 2003, p.8).

A literatura em Sociologia do Trabalho mostra que o quadro de impermanência e de

\footnotetext{
* Doutora em Engenharia de Produção pela UFSCar. Pósdoutora em Sociologia pela UFSCar. Professora do Departamento de Saúde, Educação e Sociedade da Universidade Federal de São Paulo.

Av: Ana Costa, $95-1^{\circ}$ andar. Vila Mathias. Cep: 11060001. Santos - São Paulo. fercockell@yahoo.com.br

* * Sociólogo. Doutor em Ciências Sociais. Pós-Doutorando em Sociologia.dperticarrari@yahoo.com.br

${ }^{1}$ Agradecemos à Capes pelo financiamento de parte da pesquisa.
}

descartabilidade enfrentado por essa mão de obra, juntamente com o constante desrespeito às leis trabalhistas e previdenciárias, posicionam essa população à margem dos sistemas de proteção social-trabalhista. Nesse caso, o ônus do processo de informalidade e precariedade das condições de trabalho recai mais fortemente sobre os operários menos qualificados da construção civil, uma vez que esses trabalhadores encontram-se marginalizados pelo sistema de proteção social e percebem baixos salários, além da ausência de renda fixa, o que os impossibilita de arcar com as formas mercantis de proteção social (Cockell; Perticarrari, 2008; Oliveira; Iriart, 2008; Souza, 2007; Lautier; Pereira, 1994; Morice, 1993).

A instabilidade de renda e de emprego situa os trabalhadores informais em condições de dominação maiores ainda do que apenas aquelas ligadas às condições de trabalho. Para Birh (1998), as questões de habitação, de acesso aos meios de consumo, entre outras, levam os trabalhadores a se submeterem a formas cada vez maiores de exploração.

De fato, conforme demonstrado pela lite- 
ratura, o trabalho na construção civil é popularmente rotulado como pesado, desvalorizado, discriminado e sem futuro (Oliveira; Iriart, 2005). Trata-se de um trabalho precário devido ao risco iminente de acidentes, nocividade das cargas de trabalho, más condições de trabalho nos canteiros de obra, instabilidade de emprego e de renda, alta rotatividade e, sobretudo, insuficiência de garantias contratuais e formais (Cockell, 2008; Souza, 2007). Sendo assim, muitos dos operários do setor encontram-se desprotegidos e desamparados para lidar com os momentos de infortúnio (eventos casuais e alheios à vontade humana), restando-lhes "se virar", o que, segundo Lima e Soares (2002, p.79), desonera o capital de suas obrigações, dado que "o ônus de reprodução da força de trabalho" é transferido para o próprio trabalhador.

Isso não significa, contudo, que os trabalhadores o percebam dessa maneira. Assim, este artigo tem como proposta analisar a percepção dos próprios operários sobre a desproteção social a eles imposta por meio da precarização crescente dos contratos de trabalho, as formas atuais de contrato de trabalho e como a vulnerabilidade ${ }^{2}$ desses contratos afeta suas condições de trabalho, de vida, bem como sua reprodução social.

\section{O TRABALHO NA CONSTRUÇÃO CIVIL}

O setor da construção civil possui grande importância econômica e social para o desenvolvimento do Brasil, devido a diversos fatores: volume de produção, capital circulante, expressiva quantidade e variabilidade de fornecedores de insumos, equipamentos e serviços ao longo de toda a sua cadeia produtiva, utilidade dos

${ }^{2}$ Entendemos, nesta pesquisa, por vulnerabilidade social a combinação de fatores que possam produzir resultados negativos, em consequência da relação entre a disponibilidade dos recursos materiais ou simbólicos (capital financeiro, capital humano, experiência de trabalho, nível educacional, composição e recursos familiares, experiência de trabalho, redes sociais informais e capital físico) dos atores, sejam eles indivíduos ou grupos, e o acesso à estrutura de oportunidades sociais, econômicas, culturais que provêm do Estado, do mercado e da sociedade (Filgueiras, 2001). produtos, pela redução do déficit habitacional e por sua capacidade de absorver diretamente e indiretamente uma grande parcela de trabalhadores, sobretudo a de baixa qualificação (Breitbach, 2009; Franco, 2001).

A importância econômica da indústria da construção civil é constatada em sua participação na economia nacional. Indicadores dos últimos anos divulgados pelo DIEESE e pela Fundação Sistema Estadual de Análise de Dados (SEADE) indicam que a construção civil foi o setor que mais contratou nas regiões metropolitanas de São Paulo, Belo Horizonte, Recife, Porto Alegre, Salvador e no Distrito Federal em 2007, atingindo um crescimento de $8,2 \%$, em comparação com 2006 (DIEESE, 2008).

Desde 2004, a construção encontra-se novamente em crescimento, e projeções otimistas esperam um aumento crescente do setor, considerando: a expansão do PIB nacional, o excelente desempenho dos financiamentos imobiliários, com o programa do governo Minha Casa, Minha Vida, ${ }^{3}$ a redução do IPI (Imposto sobre Produtos Industrializados), a perspectiva de liberação dos recursos do Programa de Aceleração do Crescimento (PAC), embalado pelos eventos esportivos em 2014 (Copa do Mundo) e 2016 (Olimpíadas) em território nacional. Com o PAC, o governo planeja proporcionar estímulos à expansão da infraestrutura e da oferta de habitação. Breitbach (2009) mostra que a indústria da construção civil vem apresentando, nos últimos anos, desempenho muito positivo, atingido níveis de crescimento inéditos desde a desativação do BNH (Banco Nacional de Habitação). Segundo a autora, em 2008, as estimativas apontam um dinamismo excepcional do setor, quando seu crescimento ultrapassou o da indústria de transformação brasileira. De maneira semelhante, Mello e Amorim (2009, p. 390) afirmam que

${ }^{3}$ O Governo Federal está investindo R $\$ 34$ bilhões para que milhões de brasileiros tenham acesso à casa própria. $\mathrm{O}$ Minha Casa, Minha Vida, lançado em Março de 2009, viabiliza a construção de 1 milhão de moradias para famílias com renda de até 10 salários mínimos, em parceria com estados, municípios e iniciativa privada, o que vai impulsionar a economia, gerar empregos e trazer reflexos positivos para toda a sociedade (Brasil, 2010). 
o setor da Construção Civil passa por uma grande transformação, saindo de um longo marasmo, com poucos investimentos, para um período com grandes obras em andamento e fortes investimentos imobiliários.

Dados do primeiro trimestre de 2010 fornecidos pelo Sindicato da Indústria da Construção Civil do Estado de São Paulo (SINDUSCONSP, 2010) e da Fundação Getúlio Vargas (FGV) apontam que o número de empregados na construção civil no País atingiu novo recorde histórico, com crescimento de 2,55\%, ante dezembro 2009, somando 2,604 milhões de trabalhadores empregados com carteira no setor, o que equivale à contratação de mais 147.517 trabalhadores com carteira assinada.

A grande absorção de mão de obra pelo setor desempenha, segundo Franco (1995) e Honório (2002), relevante contribuição para o desenvolvimento social do país. Para eles, a indústria da construção civil possibilita ao trabalhador com pouca ou nenhuma qualificação obter uma ocupação o que, de acordo com Lima (1995, p.12), funciona "como válvula para regular os problemas de emprego e subemprego nas áreas urbanas."

Entretanto, cabe aqui ressaltar que, em momentos de expansão, a terceirização e a nãoformalização dos vínculos não deixam de ser vistas pelos empresários como valiosas e reconhecidas estratégias na esfera da competitividade. A estratégia de terceirização na construção civil sempre buscou, por um lado, minimizar e controlar os custos diretos e indiretos mediante a contratação de empresas especializadas em serviços complementares, para os quais, segundo Franco (1995), a empresa contratante não tem conhecimento especializado. Por outro lado, tal prática passa a ser utilizada pelas construtoras direcionada exclusivamente para a subcontratação de mão de obra, com caráter substitutivo. Trata-se de uma estratégia competitiva de desverticalização ou desintegração vertical, em que firmas individuais, conhecidas como "gatos", fornecem trabalhadores especializados para as obras (Serra, 2001).

Dessa maneira, a maior oferta de empre- gos formais, nos últimos anos, é também acompanhada pela manutenção da oferta de empregos informais e presença marcante dos "gatos". Conforme observam Barros e Mendes (2003), a estratégia de gestão da mão de obra por empreitada permite às empresas do setor reduzirem os custos com produção e os encargos sociais e fiscais, deixando a cargo de terceiros a responsabilidade pelos operários, o que resulta na transferência dos riscos.

Para o presidente do Sindicato da Construção Civil de São Paulo, as medidas adotadas pelo atual governo contribuem para a aceleração

de um quadro trágico, com o trabalhador executando suas funções na informalidade, sem direitos trabalhistas como $13^{\circ}$ salário, férias, recolhimento de seus dividendos junto à Previdência e, principalmente, o incremento das tarefas (Ramalho, 2008, p.1).

Dados do Sindicato da Indústria da Construção Civil do Estado de São Paulo apontam que a informalidade ultrapassou o percentual de 70\% em 2006 (SINDUSCON-SP, 2008). Projetando esse percentual para os valores formais da construção contabilizados pelas Rais 2006 (Relatório Anual de Informações Sociais), pode-se inferir que, para o total de 359.852 trabalhadores formais no estado de São Paulo, existem cerca de 830.000 informais. O mesmo cálculo pode ser feito para São Carlos, campo desta pesquisa. Nesse caso, 1.735 trabalhadores eram formais em 2006, podendo existir aproximadamente 4000 trabalhadores informais na construção civil em São Carlos.

Embora sejam projeções, pode-se afirmar que os contratos informais são significativos, configurando-se em uma importante característica da precarização do trabalho nesse setor. A grande maioria dos trabalhadores da construção civil recebe pelas horas trabalhadas ou trabalha por tarefa, os chamados "tarefeiros" - autônomos registrados como pessoas físicas que contratam trabalhadores para obras, sem vínculo. A terceirização em empresas também contribui para a informalidade, uma vez que muitos dos 
contratos não são formalizados. Além disso, empresas formais da área utilizam a tática de assinar a carteira de apenas metade ou de uma pequena parte dos trabalhadores (SINDUSCONSP, 2008).

O que pode ser observado é que, nos últimos anos, vêm ocorrendo iniciativas locais de combate à informalidade no setor ${ }^{4}$ e maior incentivo do Governo Federal à formalização, mediante políticas públicas voltadas para reduzir a informalidade. Em todo o pais, o Governo Federal pretende regularizar a situação de um milhão de trabalhadores informais, em todos os setores, até dezembro de 2010, segundo projeções do Sebrae-SP (Serviço de Apoio às Micro e Pequenas Empresas de São Paulo, 2010). O Departamento Intersindical de Estatística e Estudos Socioeconômicos (DIEESE, 2009) explica que, apesar do incremento do número de ocupados no setor desde 2004, as ocupações geradas na construção são heterogêneas, com uma expressiva parcela de assalariados contratados de forma irregular, sem carteira assinada, e por trabalhadores que, embora contem como autônomos nas estatísticas, usufruem de pouca ou nenhuma liberdade.

Apesar dos projetos de redução da informalidade e da crescente formalização na construção civil, é importante ponderar que a literatura recente e os índices apresentados evidenciam a precariedade das condições de trabalho no setor, marcada pelos altos percentuais de acidentes e doenças do trabalho e intensificada pelas práticas de subcontratação, pela instabilidade de serviços e de renda, pela inexpressiva contribuição à Previdência Social e pela informalidade dos contratos de trabalho. A precarização existente é comprovada, portanto, tanto pela histórica falta de proteção ou regula-

${ }^{4}$ Com o objetivo de reduzir a informalidade, o Departamento Intersindical de Estatística e Estudos Socioeconômicos (DIEESE) desenvolveu o projeto "Redução da Informalidade por meio do Diálogo Social" com o suporte financeiro do Banco Interamericano de Desenvolvimento (BID). Foram selecionados quatro Arranjos Produtivos Locais para implantar o projeto - confecção em Caruaru (PE), comércio em Porto Alegre (RS), construção civil em Curitiba e agronegócio em Morrinhos (GO). mentação efetiva do Estado, quanto pelas condições reais de trabalho (falta de equipamentos de proteção individual e coletiva, contratos verbais, longas jornadas, péssimas condições de higiene dos alojamentos, banheiros e refeitórios, exposição a riscos ocupacionais, entre uma infinidade de fatores já reconhecidos e recorrentes). Sendo assim, podemos afirmar que os operários do setor vivenciam cotidianamente a nocividade de práticas já antigas e, por vezes, institucionalizadas ou aceitas como "próprias" do trabalho da construção de edificações.

\section{ASPECTOS METODOLÓGICOS}

A natureza desta pesquisa é qualitativa, devido à natureza do problema a ser estudado, da complexidade do objeto de estudo e do seu recorte. A verificação de cunho qualitativo possibilita ao pesquisador compreender as representações de um determinado grupo, analisar as relações estabelecidas entre diferentes atores sociais e apreender seus valores, ideias, concepções e "senso comum" sobre temas específicos (Minayo, 2004).

As entrevistas ocorreram entre os meses de novembro de 2006 e março de 2007, na cidade de São Carlos (SP, Brasil). Delimitou-se a amostra pesquisada por tempo de serviço no setor de no mínimo cinco anos e por idade mínima de 25 anos, excluindo, dessa forma, os biscateiros (desempregados recentes, sem especialização). Limitou-se o número de trabalhadores entrevistados a vinte, quando foi percebido que as informações obtidas ao longo das entrevistas começaram a se repetir em conteúdo, nada mais acrescentando às informações obtidas, alcançando a "saturação qualitativa" (Gondim; Lima, 2002). Todos os nomes utilizados são fictícios, preservando-se, assim, a identidade dos entrevistados. 


\section{PERFIL DOS ENTREVISTADOS}

Participaram da pesquisa vinte trabalhadores da construção de edificações da cidade de São Carlos (SP, Brasil), homens, entre 26 e 74 anos, com idade média de 44,5 anos. Desses, doze são casados, três vivem em união consensual, quatro são solteiros e um é viúvo.

A classificação profissional foi feita pelos próprios entrevistados, não tendo como critério a faixa salarial nem o registro em carteira: 01 pintor, 01 ajudante de pintor, 02 montadores de estrutura metálica, 03 serventes, 02 ajudantes de pedreiro, 07 pedreiros e 04 pedreiros responsáveis pelo acabamento da obra.

A maior parte dos entrevistados tem baixo nível de escolaridade formal. Doze não completaram o ensino fundamental e apenas três finalizaram o ensino médio, sendo que um deles tem ensino superior completo. Não entrevistamos nenhum trabalhador analfabeto, porém chama a atenção o fato de apenas três trabalhadores terem finalizado o primeiro ano do ensino fundamental.

Três trabalhadores não têm filhos e os demais têm, em média, dois filhos. O número de dependentes por entrevistado é alto, entre três a seis dependentes. Quanto às condições de moradia, onze trabalhadores moram em casa própria, com exceção de um entrevistado que ainda está financiando a casa onde reside. Dois trabalhadores moram com os pais, um com avôs e seis pagam aluguel, o que representa, no caso dos serventes, até a metade da renda mensal. As rendas obtidas pelos membros da família são, às vezes, reunidas em um orçamento comum e despendidas de acordo com as necessidades da família. Em relação à renda das esposas, observamos que, entre os quinze trabalhadores casados ou com união conjugal estável, somente sete esposas trabalham. Em todos os casos, o salário da esposa é inferior ao do marido (1 a 2 salários mínimos ${ }^{5}$ ), sendo que apenas uma das esposas não possuía registro em carteira de trabalho. A

\footnotetext{
${ }^{5}$ O salário mínimo da época era de R\$ 350,00.
}

grande maioria dos entrevistados se considera chefe da família, por serem homens, provedores, mais velhos e responsáveis pela família.

Antes de trabalhar na construção de edificações, todos os operários desempenharam outras funções. Dezoito trabalhadores iniciaram suas atividades no campo, nem sempre remuneradas, principalmente quando o empregador era o pai ou outros membros da família. Todos os entrevistados começaram a trabalhar ainda jovens, em média com 11 anos de idade. Constatou-se que sete entrevistados já trabalhavam com menos de dez anos de idade, fato considerado por alguns trabalhadores como limitador da continuidade do ensino fundamental.

Vou falar a verdade para você: tinha 7 anos de idade quando comecei a trabalhar. Trabalhava na lavoura de café. Aí não deu para estudar. Fiz só o primeiro ano. Na escola da fazenda. Nem documento eu tenho. Não sou analfabeto, sei ler e faço conta de cabeça. Tinha que ajudar o pai, senẵo faltava comida em casa. Graças a Deus, pude dar estudo para minha filha. Ela não teve que parar de estudar (Antônio, 60 anos, pedreiro).

Do campo até a construção, foram vários os caminhos trilhados pelos dezoito entrevistados de origem rural. Entre eles, Antônio, Diego, Mário, Isaac, Matheus, Danilo e Francisco tiveram o segundo emprego na construção de edificações. Entretanto, somente Antônio e Diego continuaram trabalhando no setor desde a época em que deixaram o campo em sua cidade natal.

Do total pesquisado, doze entrevistados trabalharam em empresas metalúrgicas na cidade de São Carlos antes de começarem na construção civil, e um entrevistado continuava trabalhando ao mesmo tempo em uma metalúrgica e na construção civil.É imperioso mencionar que a cidade de São Carlos é conhecida por ser um polo científico e tecnológico, em virtude das pesquisas de ponta na Universidade de São Paulo (USP) e na Universidade Federal de São Carlos (UFSCar) e devido à aglomeração de empresas de alta tecnologia.

A oferta de emprego no setor secundário motivou trabalhadores nascidos na região de São 
Carlos e migrantes de outras regiões a procurarem empregos nas indústrias da cidade. Até a década de 90, não havia grandes exigências de qualificação profissional ou escolaridade. Como explica Expedito, 74 anos, as indústrias contratavam trabalhadores recém-chegados da zona rural, sem experiência e com pouca escolaridade. Segundo ele, quando entrou na CBT (Companhia Brasileira de Tratores) em 1963, "eles só me perguntaram se eu sabia ler, nem precisava saber escrever”.

Os depoimentos mostram que as trajetórias ocupacionais dos entrevistados foram transformadas pela alta rotatividade da mão de obra no setor metalúrgico ou, principalmente, em decorrência do movimento de reestruturação produtiva. Esse novo paradigma de produção demandou um novo perfil de trabalhador com maiores níveis de escolaridade, multifuncional, flexível, polivalente, criativo, com iniciativa e com capacidade de trabalhar em grupo (Gitahy, 1994), além de disposto a colaborar com os novos ideais das empresas. Apesar de restrito a um tipo determinado de perfil profissional, mais velho e com baixa escolaridade (com exceção de Moisés), as entrevistas apontam que o emprego informal na construção civil de São Carlos foi um dos destinos para os trabalhadores fabris demitidos com a reestruturação industrial.

\section{INSTABILIDADE DE EMPREGO E DE RENDA: a precariedade dos contratos de trabalho}

A partir da descrição das trajetórias ocupacionais, pode-se afirmar que vários entrevistados, até então trabalhadores estáveis e com algumas garantias, passaram, nas últimas décadas, a fazer parte da massa flutuante de trabalhadores instáveis, tanto pelo processo de reestruturação produtiva em outros ramos, pelo processo de subcontratação na indústria de edificações e pela ampliação do setor de serviços, quanto pelo crescimento das taxas de desemprego nos setores primário e secundário.

Atualmente, esses operários trabalham sob vários tipos de vínculos - empregados próprios, de terceiros, autônomos - sendo remunerados por hora, por semana, por empreitada ou por tarefa. Segundo Souza e Melhado (1991), os operários podem ser contratados para trabalhar de várias maneiras: a) pela disposição da Consolidação das Leis de Trabalho (CLT) por tempo indeterminado - nesse caso, pode haver um período de experiência inicial de, no máximo, 90 dias, não acarretando ônus para o contratante a dispensa ao término desse período; b) pela disposição da CLT por tempo determinado - pode ser acertado por no máximo dois anos, como prorrogação de mais um ano; c) como autônomo; d) por meio de subempreiteiras de serviços; e) por meio de subempreiteiras de mão de obra.

Os vínculos de trabalho dos entrevistados são bastante heterogêneos. Três trabalhadores foram contratados por construtoras da cidade por meio da CLT por tempo indeterminado: Anderson e Douglas, montadores de escoramentos metálicos, e Diego, especializado em acabamento final. Já Antônio foi contratado por uma igreja católica, pela disposição da CLT, por tempo determinado, ou seja, durante o período da obra, com duração máxima de um ano e meio. Todos os demais entrevistados declararam não ter assinado ou estabelecido nenhum tipo de contrato escrito com os empregadores, como empreiteiros, engenheiros e construtoras, ou com os contratantes do serviço. Mesmo no caso específico dos trabalhadores genuinamente autônomos, quando questionados sobre o serviço atual, todos afirmaram que não emitem nota fiscal como autônomo pelo serviço realizado ou recibo com o valor do serviço. Para Moisés:

Nestes anos todos que trabalho por conta nunca assinei ou dei recibo para nenhuma empresa. Quando é serviço pequeno é boca a boca. É geralmente serviço que você faz em uma semana, dois, três dias, né? Então, nem compensa ter contrato. Lógico, faz um recibinho, isso e aquilo, mas é coisinha. Mas, quando é serviço que você vai ficar lá três, quatro meses em uma obra, aí a gente tem que fazer, né? [- Por que, neste caso, você faz recibo?] É mais para o cliente também, exatamente, né? Para mim até hoje não deu problema nenhum. Quando é assim, no final do serviço, quan- 
do vou receber, faço um recibo com o valor que eles tem que me pagar. Mas, acho que tem muito tempo que ninguém me pede (Moisés, acabamento final).

Prevalece, então, para dezesseis dos entrevistados, o contrato verbal, comumente por eles denominado "contrato de boca". A associação entre o contrato verbal e a masculinidade dos entrevistados encontra-se fortemente presente nos discursos; segundo eles: "Não temos contrato escrito, nosso contrato é de homem" ou "Não tenho contrato escrito. Tudo foi feito na palavra de dois homens. Quem for sacana, não é macho suficiente para arcar com sua palavra, não merece respeito" ou, até mesmo "homem que é homem, sua palavra basta”. Ao imputar a fragilidade dos contratos do trabalho a questões relativas à honra, os trabalhadores incorporam a ideologia defensiva, ou seja, negam a instabilidade vivenciada pelos contratos verbais, condicionando a relação estabelecida apenas na palavra dos envolvidos. O grupo transforma a aparente volubilidade do contrato verbal, em uma situação mais sólida, menos sujeita a mudanças, ou seja, para eles, o contrato verbal só não será cumprido caso não estejam lidando com pessoas com honra, do ponto de vista dos entrevistados, "homens de verdade". Para Dejours (1987), a ideologia defensiva permite mascarar, conter e ocultar uma ansiedade particularmente grave, sendo funcional para o grupo, quando elaborada coletivamente contra perigos e riscos reais.

A forma de pagamento dos entrevistados varia em função do tipo de inserção no mercado de trabalho. No entanto, diante da multiplicidade de conceitos em torno do termo informalidade e das divergências encontradas entre a percepção dos entrevistados e a literatura, será considerada informal toda relação de trabalho construída à margem da legislação vigente. Sendo assim, dos vinte entrevistados, quatro são formais, uma vez que possuem contratos de trabalho regularmente regidos pela CLT, ou seja, têm garantidos os direitos trabalhistas e previdenciários. Por outro lado, a maior parte dos entrevistados ocupa empregos informais, sem carteira de trabalho assinada e sem contribuição previdenciária.
Em relação aos trabalhadores autônomos, encontramos divergências entre a contribuição para o INSS com a verdadeira relação estabelecida entre o trabalhador e o contratante. Os entrevistados Marcos, José, Dunga, Isaac e João Batista contribuem atualmente para o INSS na categoria autônomo. Nesse caso, com exceção do entrevistado José, o tipo de relação de trabalho estabelecida não configura, portanto, segundo o ponto de vista desses trabalhadores, uma relação autônoma de trabalho, embora sejam regularizados junto ao INSS. Apenas o pintor José se considera autônomo, pois: "trabalho por conta, não sou explorado por ninguém. Sou meu chefe e ao mesmo tempo trabalho".

Cabe aqui ressaltar que, provavelmente, esses trabalhadores não contribuirão continuamente para o sistema previdenciário, uma vez que, analisando as suas trajetórias ocupacionais, constatamos que a maior parte do tempo de contribuição ocorreu no período no qual eram registrados. Como autônomos, começam pagando nos primeiros meses, mas, com o tempo, muitos deixaram de pagar e acabaram abandonando definitivamente a Previdência Social. Dunga e Isaac começaram a contribuir com a previdência depois do acidente ocorrido com o entrevistado Paulo. Segundo Dunga:

Comecei a pagar com autônomo em 2004. porque ia apertar se um dia ficasse doente. Vi o rapaz que trabalhava com nós lá [refere-se ao entrevistado Paulo]. Ele adoeceu, ficou parado e não ganhou nada. Se ele tivesse registrado, pagado como autônomo, não tinha passado dificuldade. Nós tivemos que fazer vaquinha. Meu tio [o empreiteiro] ficou pagando o salário dele, mesmo sem ele trabalhar. Ele ficou doente com pneumonia e tinha família para sustentar. Na época que eu vi o quadro ficar preto, pensei: é melhor pagar carteira, porque amanhã pode ser comigo. Ele foi um aviso, vê quem quer. Foi ideia minha, mas a mulher também falou comigo. Sei que ela tem carteira, o que dá uma tranquilidade para as crianças, mas se eu fico doente, fica só o salário dela para 5 bocas (Dunga, pedreiro).

Por outro lado, Marcos e José passaram a contribuir como autônomos diante da constatação da perda da capacidade produtiva com o envelhecimento. Para Marcos: 
Sempre achei que era frescura pagar, que era rasgar dinheiro. Só que, quando a idade foi chegando, fui me dando conta da necessidade. Tem sete anos que comecei a pagar. Vi que eu tava ficando velho (Marcos, pedreiro).

Em relação aos contribuintes individuais da Previdência Social, com ressalva do pintor José, todos trabalham para empreiteiros, subcontratados, sendo remunerados pelo dia de trabalho. Para eles, contribuir para o INSS não significa trabalhar como autônomo. Autônomo é "trabalhar por conta, ser responsável pelo trabalho, não ser explorado por gato", "poder vender seu serviço pelo seu preço, sem ninguém tirar vantagem na suas costas" ou "ter que conseguir clientes, ter que tomar conta de tudo e poder executar sua parte do seu jeito".

Diante dessa constatação, torna-se incompatível considerar unicamente a contribuição ao INSS (relação entre trabalhador e Estado) para categorizar os entrevistados autônomos, uma vez que a percepção dos trabalhadores é divergente com relação a esse critério. Além disso, vale ressaltar, conforme foi mencionado anteriormente, que nenhum dos entrevistados autônomos assinou qualquer forma de contrato pela prestação de serviço, nem emitiu nota fiscal ou recibo (relação entre trabalhador e contratante do serviço). Entretanto, não foi encontrada, na literatura, classificação alguma que, ao mesmo tempo, considerasse parâmetros tão distintos. Sendo assim, neste texto, para evitar as armadilhas em torno do conceito de autônomo, eles serão categorizados da seguinte maneira: autônomo regularizado - o trabalhador contribui para o INSS e, além disso, se considera trabalhador por conta própria, como no caso do entrevistado José; autônomo assalariado disfarçado - o trabalhador paga o INSS, mas ocupa atividades precárias e assalariadas dentro do "mercado formal" e, por isso, não se considera autônomo (entrevistados Marcos, Dunga, Isaac e João Batista); e, por último, autônomo não-regularizado - o trabalhador não regulariza a situação de autônomo, porém trabalha por conta própria ou presta serviço, com o objetivo de se autoempregar, como
Moisés e os irmãos Danilo e Francisco, podendo engajar familiares ou ajudantes assalariados.

Entre os autônomos não-regularizados, Moisés não paga o INSS porque “... não está sobrando dinheiro. Eu tenho uns quinze a vinte anos de contribuição. Eu trabalhei desde criança, desde moleque. Vou me aposentar por idade". Por ora, Danilo não pode contribuir porque está recebendo seguro-desemprego, e Francisco porque é registrado na fábrica de compressores. Do ponto de vista deles, ser autônomo significa trabalhar sem intermediários entre eles e o proprietário do imóvel, ou trabalhar por empreita recebendo pelo serviço prestado, com autonomia e sem terceiros tirando proveito financeiro dessa relação. Ou seja, ser autônomo é ser "dono do próprio nariz".

No total, onze trabalhadores encontram-se desprotegidos do sistema de seguridade social. As principais justificativas para tal situação foram: falta de recursos, baixa credibilidade do sistema, insuficiência de conhecimento, expectativa em aposentar por idade e desesperança quanto ao futuro, como se evidencia na fala a seguir:

Eu acho que não tem futuro nenhum este negócio de ficar pagando como autônomo. Aposentar eu não vou mesmo. Independente de eu ter ou não carteira assinada, eu não vou aposentar. Eu não vou pagar. Por que eu acho que é tudo ladroagem este negócio de ficar pagando como autônomo. Se você for registrado numa firma tudo bem, mas pagar como autônomo, de jeito nenhum! [- Por que você não pagaria como autônomo?]. Sei lá, é um sentimento. Acho que não vou viver até lá. (Lucas, acabamento final).

A partir das entrevistas realizadas com os operários de São Carlos, foi possível ainda compreender como a percepção da informalidade encontra-se diretamente relacionada com a apropriação da força de trabalho por terceiros, marcada pela precariedade dos contratos, situação em que a relação estabelecida configura-se como subordinada ao sistema de acumulação capitalista. A esse respeito, Cacciamali (2000) explica que, com a reformatação das relações de trabalho, surgem formas de trabalho assalariado não-registrado junto aos órgãos da seguridade 
social, juntamente com contratações legais ou consensuais, dissimuladas sob a forma de trabalho autônomo, como cooperativas de trabalho, empreiteiras de mão de obra, agências de trabalho temporário, locadoras de mão de obra e prestação de serviços temporários.

O caso de João Batista mostra como os mecanismos de subcontratação e de prestação de serviços substituem progressivamente o trabalho assalariado. João Batista, especializado em acabamento final, trabalha há oito anos para uma das maiores construtoras no setor de edificações. Nos dois primeiros anos, trabalhou registrado pela construtora. Contudo, desde então, passou a ser pago por dia de trabalho, por uma empreiteira de mão de obra. Para burlar a fiscalização, a empreiteira repassa mensalmente o valor da contribuição do INSS, para que João Batista possa contribuir como autônomo. Segundo ele:

Eu sou recomendado a dizer que sou autônomo, se a fiscalização aparecer. Mas não emito nenhum recibo como prestador de serviço. A diferença é que, antes, eu era registrado. Só que há seis anos continuo fazendo a mesma coisa, porém agora recebo do gato pelo dia de trabalho e não tenho mais férias nem décimo terceiro. Por fora, ele me dá o valor para eu pagar o INSS e aliviar para o lado dele e da construtora. (João Batista, acabamento final).

Essa mesma situação foi vivenciada pelo entrevistado Thiago:

Hoje eu não estou contribuindo. Antes, quem estava contribuindo para mim é o dono das obras, o Luís Fernando. Eu trabalhava para ele nas obras dele aí ele contribuía para mim, como seu eu fosse autônomo, sabe? Ele vivia dizendo que era para eu pagar, porque, se a fiscalização chegasse e eu não dissesse que trabalhava por conta, ficaria ruim para o lado dele. Mas eu falava que não sobrava dinheiro. Então, ele começou a pagar. Mas o pintor que eu trabalhava para ele, que também trabalhava para o Luís Fernando, saiu das obras. Aí tive que sair também. Aí ele parou de pagar. Eles me deram o carnê, mas hoje eu estou sem condições de pagar. Para o pintor foi bom porque ele [refere-se ao entrevistado José] recebe mais trabalhando por conta. Mas, para mim foi ruim, porque ele me paga a mesma coisa, mas fiquei sem o carnê (Thiago, ajudante de pintor).

Dessa maneira, os contratantes (construtoras, empreiteiras ou proprietário do imóvel) eliminam os custos trabalhistas não-salariais, deixando de recolher as contribuições sociais previdenciárias exigidas para a regularização da obra. O sentimento de vulnerabilidade ocasionado pelo trabalho não-regularizado é exposto repetidas vezes no decorrer das entrevistas e expressa a desproteção por eles vivenciada no emprego das seguintes expressões: "não temos direito nenhum", "meu único direito é de trabalhar", "ser informal é não saber como vai ser o dia de amanhã", "não dá para pensar em aposentar, se hoje não tenho proteção nenhuma", "só consigo pensar um dia de cada vez", "trabalhar assim só não é pior do que ficar sem emprego" ou "o informal não tem direito de sonhar". Pode-se dizer, efetivamente, que eles não conseguem planejar o futuro, porque o presente é instável.

Para os entrevistados, trabalhar na informalidade significa, principalmente, não ter a carteira de trabalho assinada. Popularmente, representa a falta de compromisso moral do empregador em seguir a legislação, restringindo o acesso aos direitos constitucionalmente assegurados, posicionando-os na categoria de "précidadãos" ou "cidadãos de segunda categoria" (Santos, 1987). Na mesma direção, trabalhadores acidentados da construção civil da cidade de Salvador (BA) afirmam que o trabalho informal denota: "perda de tempo", "trabalho em vão", "trabalho sem valor", "trabalho inútil" e "trabalho à toa” (Oliveira; Iriart, 2005). Representa ainda a ausência de direitos trabalhistas e previdenciários, principalmente no que se refere à aposentadoria remunerada e ao auxílios-acidente, além da incerteza de ganhos financeiros e da disparidade de tratamento em relação aos trabalhadores formais.

\section{RENDA EXTRA: o papel do "bico" para os operários da construção de edificações}

Em relação aos ganhos financeiros, não foram constatadas grandes disparidades na renda dos trabalhadores formais, informais ou au- 
tônomos, assalariados disfarçados, com exceção dos trabalhadores autônomos regularizados e não-regularizados. Entretanto, quando se compara o salário indireto (férias, hora-extra remunerada, $13^{\circ}$ salário, vales, seguro-desemprego, salário-família, etc.) verifica-se que o salário real dos informais é menor.

Ao analisar a forma de pagamento, de acordo com a ocupação dos entrevistados, considerando ainda a relação contratual, percebe-se que todos os trabalhadores registrados pela CLT são remunerados mensalmente. Entre eles, Antônio recebe mil reais por mês; no entanto, do valor embolsado, retira cinquenta reais por semana para pagar seu ajudante Pedro. Os montadores Anderson e Douglas recebem quinhentos e trinta reais líquidos por mês, e o entrevistado Diego setecentos e vinte reais.

O pagamento por empreitada ou por serviço é predominante entre os entrevistados autônomos. Nessas condições, os autônomos nãoregularizados, contratados temporariamente para a prestação de serviços, obtêm maiores rendimentos. A renda média dos autônomos nãoregularizados e do autônomo regularizado (operário José) varia entre mil a dois mil reais, podendo chegar até dois mil e quinhentos. A jornada diária de trabalho é maior, quando comparada com a dos demais entrevistados, pois, frequentemente, trabalham nos fins de semana para finalizar o quanto antes o serviço, ou ainda trabalham à noite e aos domingos, em obras realizadas em estabelecimentos comerciais.

Quanto à forma de pagamento dos demais trabalhadores não-regularizados, não há muita diferença entre os informais e os autônomos assalariados disfarçados, pois, na prática, trabalham todas as semanas, em princípio de segunda a sexta-feira, remunerados por dia, semana, quinzena ou mês, sem nenhum tipo de contrato de trabalho. Tal situação não configura trabalho temporário ou "bico"; pelo contrário, muitos recebem há vários anos o pagamento pelo dia ou pela quinzena de trabalho.

Os pedreiros Dunga e Isaac, autônomos assalariados disfarçados, recebem a cada 15 dias quarenta reais pelos dias trabalhados, enquanto Marcos, também autônomo assalariado disfarçado, contratado pelo mesmo empreiteiro Antenor - ganha cinco reais a mais, devido aos doze anos de trabalho. A jornada de trabalho desses entrevistados vai de segunda a sexta-feira, das sete às dezessete e trinta, com intervalo de uma hora para o almoço. Trabalham ainda para o mesmo empreiteiro os entrevistados Paulo e Mário, ambos serventes. Em comum, todos os contratados do Antenor recebem, no final do ano, um "salário" extra, prática incomum no setor.

O pedreiro Matheus e o Lucas trabalham por empreitada, subcontratados por empreiteiros, obtendo uma renda mensal entre mil a dois mil reais. No trabalho por empreitada, os entrevistados calculam o preço pelo metro quadrado ou pelo serviço prestado, recebendo acima do valor do dia de trabalho. Entretanto, estendem a jornada de trabalho de domingo a domingo para conseguir finalizar o serviço contratado no menor tempo possível. Do mesmo modo que os autônomos, Matheus e Lucas enfrentam constantemente instabilidade de renda, mas, por outro lado, vivenciam menor inconstância de serviços, pois, de acordo com Matheus: "os empreiteiros têm melhores contatos e, por isso, sempre têm serviço. Assim, não preciso correr atrás de várias pessoas, nem manter contatos bons. Acaba um serviço, é só ligar para os empreiteiros e falar que estou disponível”.

O entrevistado João Batista, autônomo assalariado disfarçado, recebe do "gato" quarenta reais por dia de trabalho, totalizando oitocentos por mês, enquanto Diego, contratado pela mesma construtora, porém pela CLT, recebe setecentos e vinte reais por mês. João Batista explica que o "gato" sempre justifica a diferença de oitenta reais como um "bônus" para o pagamento do INSS.

Para Lima (1995), essa multiplicidade de formas de contrato de trabalho resulta em distorções e gera atritos entre os diversos trabalhadores atuantes nos canteiros de obra, dificul- 
tando o trabalho em equipe e o engajamento dos trabalhadores nas políticas da empresa. No caso das grandes construtoras, há uma tendência de o tipo de remuneração e de vínculo determinar a tarefa que será executada por cada trabalhador dentro do canteiro de obras. A esse respeito, Serra (2001) relata também que algumas construtoras mantêm um pequeno número de trabalhadores registrados para eventuais necessidades, como o entrevistado Diego, que trabalha na mesma construtora de João Batista, porém com carteira de trabalho assinada.

A categoria servente é remunerada pelo dia de trabalho ou pela quinzena. O valor da diária varia de vinte e cinco a trinta reais. Paulo, servente há onze anos, explica que o preço do mercado, na cidade de São Carlos, é de vinte reais para os iniciantes e vinte cinco para os serventes mais experientes. Porém ele recebe trinta reais, porque "com os anos de dedicação, me tornei amigo do gato, ele é um irmão para mim”.

Entre os ajudantes de pedreiro entrevistados, o valor da jornada de trabalho é inferior ao da categoria dos serventes. O ajudante Pedro recebe do pedreiro Antônio vinte reais por dia de trabalho, de segunda a sexta-feira, enquanto o outro ajudante, Abraão, recebe em média cinquenta reais semanais do entrevistado Moisés, podendo chegar a setenta e cinco se trabalhar nos fins de semana. Thiago, ajudante de pintor, embolsa vinte e cinco reais por dia de trabalho. A despeito da maior carga de trabalho e da maior qualificação dos ajudantes em relação aos serventes, o salário dos ajudantes entrevistados é inferior ao dos serventes. Nossa hipótese é de que os ajudantes são contratados por profissionais autônomos, enquanto os serventes entrevistados trabalham para empreiteiros e para uma construtora, os quais, por sua vez, auferem maiores lucros, tornando plausível, dessa forma, maior remuneração.

Em relação aos contratantes, todos os entrevistados afirmaram que ser contratado diretamente pelo proprietário da obra possibilita maiores rendimentos, principalmente nos em- preendimentos localizados nos condomínios residenciais. Porém são unânimes em afirmar que esse tipo de serviço encontra-se concentrado na mão dos grandes empreiteiros e engenheiros.

Parece existir um consenso quanto ao valor da remuneração quando os contratantes são os empreiteiros, um tipo de "código de ética" ou "tabela". Os trabalhadores entrevistados afirmaram que o valor pago pelo dia de trabalho varia de acordo com a experiência no setor, com o tipo de atividade e com a cidade. De acordo com eles, em São Carlos, o dia de trabalho do servente varia entre 20 e 30 reais, do ajudante de pedreiro entre 25 e 35 reais, do pedreiro entre 30 e 45 reais e de pedreiros especializados no acabamento da obra de 40 a 60 reais. Trabalhadores aprendizes e ocasionais recebem cerca de dez reais a menos. Valores inferiores a esses somente são aceitos quando os contratantes são trabalhadores autônomos (como no caso dos entrevistados Abraão e Pedro); caso contrário, remunerações inferiores são vistas como "exploração", "sacanagem" ou "escravidão". Lautier (1993, p.28) afirma que os empregadores das micro e pequenas empresas não-declaradas não podem "impor salários muito baixos, dada a difusão da informação, à existência de um código de boa conduta e à necessidade de manter relações nãoconflituais com seus parentes e amigos". Pedro explica a diferença entre o valor pago por um empreiteiro e por um profissional autônomo:

Eu fui procurar o Antônio. Não gosto de voltar no mesmo lugar. Gosto sempre de ir para frente. Sempre sou chamado para ir trabalhar com outros empreiteiros, mas não é por causa de $10 \mathrm{cru}-$ zeiros a mais que eu vou deixá-lo. Outro dia foi um rapaz lá em casa e perguntou se eu queria trabalhar para ele. Ele disse que me garantia serviço para uns dois anos. Perguntou quanto eu tava ganhando, eu disse 20 cruzeiros e ele me disse que pagava 25. Não vou. Fica chato. Sei que o valor do Antônio é menor, porque ele trabalha por conta própria. Se ele fosse um empreiteiro seria sacanagem comigo. Ninguém aceita ganhar menos dos empreiteiros. Agora, os autônomos, como o Antônio, estão na labuta como a gente (Pedro, ajudante de pedreiro).

A maior parte dos entrevistados percebeu diminuição da renda mensal nos últimos 
anos. Para muitos, a maior concorrência no setor e o aumento da informalidade vêm progressivamente afetando os ganhos obtidos, mesmo após a aceleração do setor pelo PAC. Para o pedreiro Antônio, na década de oitenta e no início dos anos 90, era mais fácil, pois "não precisávamos trabalhar aos fins de semana para completar a renda. Hoje tem gente que por metade do preço faz o serviço. Você pode até ser melhor, mas não dá para cobrar caro. Ai a gente abaixa o preço e acaba tendo que trabalhar mais para tirar o mesmo no final do mês”.

Para compensar a redução da renda mensal, os operários da construção civil utilizam cada vez mais o tempo destinado ao lazer para executar serviços extras, os conhecidos "bicos", objetivando melhorar os baixos salários da categoria. Os ganhos mensais dos entrevistados são majorados principalmente com a realização dos "bicos" de fim de semana ou após a jornada de trabalho. Metade dos entrevistados faz "bicos" para aumentar a renda; desses, apenas Isaac é vigia noturno nos fins de semana, e Paulo limpa terrenos baldios e ajuda a carregar caçamba. Não realizam serviços relacionados com o trabalho na construção. Todos os demais trabalham por conta própria aos sábados e, esporadicamente, aos domingos. Antônio ainda realiza pequenos serviços após o horário do expediente, e Moisés ministra cursos de pintura em lojas especializadas, nos finais de semana. Em média, os trabalhadores aumentam entre duzentos a quatrocentos reais a renda mensal com a realização dos "bicos".

Além dos "bicos", quatro trabalhadores possuem ganhos extras com o recebimento de aluguel e criação de cavalos. A renda obtida com o aluguel de casas e com o arrendamento de terrenos aumenta em quase $30 \%$ os ganhos mensais dos entrevistados Pedro, Diego e João Batista. Douglas explica que todo o dinheiro poupado como montador é aplicado na compra de cavalos para, em seguida, vendê-los por um preço maior:

Eu crio cavalo. Faço de vez em quando uns rolinhos de cavalo. Eu pego o dinheiro que junto como montador e compro cavalo. Eu tenho cinco cavalos. Eu gosto. Eu deixo os meus cavalos lá perto de casa e os outros na chácara da minha irmã. Trato bem! Compro ração, deixo em ordem. (Douglas, montador).

Trata-se também de uma estratégia para garantir renda extra e segurança financeira caso fique desempregado ou diante de um problema de saúde. Observamos ainda outras estratégias utilizadas pelos trabalhadores para aumentarem a renda, como no caso dos aposentados Abraão, Pedro e Expedito e dos irmãos Danilo e Francisco, ambos metalúrgicos, que dividem a jornada de trabalho entre a construção e a metalurgia.

\section{REPRESENTAÇÕES SOCIAIS: o trabalho na construção civil}

Metade dos entrevistados declarou gostar de trabalhar na construção civil. Para esse grupo, há uma série de elementos positivos, entre eles a alegria do ambiente de trabalho, a relação com os colegas, a liberdade, a autonomia, a falta de chefe, a possibilidade de trabalhar por conta própria, menor pressão de tempo, maior capacidade de consumo, possibilidade de acumular renda para retornar para o campo e menor rigidez da organização do trabalho. Antônio, Danilo, Francisco, Diego, Lucas, Marcos e Matheus afirmaram ainda que se sentem realizados em trabalhar na construção civil pelo orgulho do fazer e o prazer de construir:

Gosto muito. É o tipo de serviço que você come-
ça a trabalhar, acaba o dia e você nem vê. É a pro-
fissão que eu aprendi, é a única coisa que eu faço
bem, por isso eu gosto. Sou bom. As pessoas me
valorizam. Falam bem do meu trabalho, da mi-
nha discrição, sou quieto, aí não incomodo nin-
guém. Conheço muita gente também. (Diego, aca-
bamento final).

Esses sete trabalhadores não veem suas funções como inferiores, nem carregam em suas falas o peso do estigma historicamente atribuído à profissão como trabalho de "peão". Por outro lado, divergem nas opiniões quando são questionados se gostariam que os filhos trabalhassem 
na construção. Apenas Matheus, Marcos e Diego explicam que seus filhos poderiam seguir essa profissão, caso fosse a vontade deles.

Se meus filhos quiserem ser pedreiro eu vou apoiar, por que não? Se quiser fazer um curso de medicina, engenharia, o problema é dele. Eu acho que cada um faz sua escolha. O trabalho de pedreiro é um trabalho como outro qualquer. Vou achar bom ensinar o ofício, mostrar tudo que sei. Mas, por enquanto, só tive menina, acho que elas não vão querer. Mas, se nascer um moleque, vou levar para o trabalho comigo. (Diego, acabamento final).

Por outro lado, Danilo e Francisco não gostariam que seus filhos trabalhassem na construção, uma vez que afirmam sofrer com que os outros pensam a respeito da atividade de pedreiro. Acrescentam que, mesmo explicando que eles sentem prazer de trabalhar na construção e que ganham melhor do que como metalúrgicos, são frequentemente questionados sobre o porquê de exercerem um serviço pesado e sujo:

Se eu estou com o uniforme da fábrica ninguém me olha estranho. Mas, se eu entro no banco, em uma loja, sujo de cimento e de tinta, já me olham atravessado. Acho que, para agradar, sempre me perguntam por que um rapaz novo, com estudo, com boa aparência, não larga este trabalho sujo, pesado. Já até falaram que, se eu parasse, minha mão ia ficar menos calejada, com melhor aparência. (Francisco, pedreiro).

Moisés, formado em Direito, explica que se sente mais feliz e realizado profissionalmente como pedreiro do que na época em que era metalúrgico ou quando tinha o açougue, mas percebe, nas pessoas, o sentimento de "pena por ser formado e trabalhar como pintor. Eu não tenho vergonha, gosto, mas as pessoas acham que é trabalho de gente sem estudo. Minha mãe evita falar para os outros o que eu faço”.

A atribuição social negativa da profissão aparece na fala de Lucas. Apesar de se identificar como pedreiro, de gostar de seu serviço e de não planejar trabalhar em outro tipo de função, Lucas afirma que, "de jeito nenhum, aceitaria que meu filho fosse pedreiro. É um serviço pesado e instável. Quero que ele faça qualquer outra coisa, menos isto".
A outra metade dos entrevistados ou se percebe como pessoas diminuídas perante a sociedade pela falta de estudo, o que não lhe permite pleitear melhores serviços, ou se identifica com as outras profissões já exercidas. Eles veem a construção civil como uma etapa passageira, mesmo que já desempenhada por vários anos, ou como a ultima opção que lhes resta. Nesse grupo, todos afirmaram que não aspiram ao mesmo futuro para seus filhos, sendo que os mais jovens demonstram não estar contentes com a atividade desenvolvida, chegando a afirmar que, desejam, futuramente, trocar de serviço.

Trabalho aqui não por gostar, mas foi o que apareceu. Por falta de serviço. Ainda vou trabalhar em uma metalúrgica. Mas, para trabalhar na Volks [fábrica de motores] tem que ter curso. Tem que ter pelo menos curso técnico de mecatrônica, eletrônica. Eu vou começar a estudar, não sei quando, mas quero fazer um curso técnico. Eu fazia mecatrônica, mas tranquei minha matrícula e parei por falta de grana. Era curso profissionalizante. Não adianta ter só segundo ano. Olhe quanto ex-metalúrgico está trabalhando aqui para o patrão. Não estudaram e agora têm que pegar no pesado. Não quero isso para meu filho. Não merece. Vai fazer faculdade, não ficar sujo de cimento. ${ }^{6}$ (Anderson, montador).

No caso dos ex-metalúrgicos, com exceção de Moisés e Marcos e dos irmãos Danilo e Francisco, todos os demais (oito entrevistados) continuam se identificando como metalúrgicos e se culpabilizam por ter de trabalhar na construção, devido à baixa capacidade de adaptação frente às novas exigências ${ }^{7}$ do mundo do trabalho e das organizações. Para eles, a "pouca iniciativa" de estudar ou mesmo a "preguiça” de buscar melhores qualificações foram as responsáveis por excluí-los das indústrias metalúrgicas.

${ }^{6}$ Lautier e Pereira (1994) descrevem que alguns operários buscam apagar toda marca de cimento ou de pintura ao sair do canteiro e vestem o melhor que podem. Assim, conseguem negar, fora do espaço de trabalho, sua identidade de trabalhador. Para eles, esse forma de negação pode representar um sinal de mobilidade para outro tipo de emprego.

${ }^{7}$ A esse respeito, Castel (2003) afirma que, junto com o desemprego e a precariedade das condições de trabalho e da individualização das tarefas e trajetórias profissionais, há também uma responsabilização dos sujeitos. Cada um passa a encarregar-se de si mesmo, buscando ser bem sucedido, sob a ameaça permanente do desemprego. 
Eu mereço, vou falar a verdade para a senhora. Eu estou aqui, trabalhando no sol e no pesado, porque não estudei. Não faltou oportunidade, tive pouca iniciativa. Eu sou mecânico dos bons. Não tinha um que fosse bom como eu. Se tivesse cabeça, um pouco menos de preguiça, tinha crescido lá dentro. Quem sabe nem tinha lesionado a coluna, né? Eu me culpo por isso, se tivesse mais do que a primeira série, eu poderia trabalhar em outro posto e não tinha me acidentado. Aí, quando a CBT fechou, eu ia conseguir emprego nas fábricas da cidade, porque ia ter curso e coluna boa. (João Batista, acabamento final).

Thébaund-Mony e Druck (2007, p.26) explicam que a mesma lógica que incentiva a constante inovação tecnológica atinge impiedosamente a força de trabalho, transformando-os em "obsoletos e descartáveis, homens que devem ser 'superados' e substituídos por outros 'novos' e 'modernos', isto é 'flexíveis"'. Vivemos, para elas, "o tempo de novos (des) empregados, de homens empregáveis no curto prazo, através das (novas) e precárias formas de contrato, e, dentre elas, a terceirização/subcontratação ocupa lugar de destaque".

Esses “(des) empregados” não percebem como os processos de reestruturação produtiva e de terceirização levaram à destruição das ocupações por eles exercidas, após a alta inserção de tecnologia e maior exigência de qualificação. Ao contrário, eles se sentem responsáveis por não se dotarem de "meios e atributos (novos) exigidos pela reestruturação em curso para ter empregabilidade", ou seja, por não conseguirem ser "flexíveis", capazes de "se adaptar facilmente a novas situações, que têm iniciativa, que são ágeis" (Thébaund-Mony; Druck, 2007, p.26). Quando muito, conseguem, em parte, culpar o "dono" da empresa pelo mau gerenciamento e, consequentemente, pela falência e venda das empresas nas quais trabalhavam e, por vezes, percebem a entrada dos mais jovens como um dos motivos que os impedem de retornar ao mercado de trabalho formal.

Quando a CBT fechou, fui procurar emprego nas metalúrgicas, porque sou metalúrgico. Mas já era velho e sem estudo. Tinha muito moleque novo, sem saber nada de chão de fábrica, que conseguia emprego. Eles deviam chamar a gente e mandar fazer, testar. Aí eu queria ver moleque tirar trabalho meu. Hoje, já consegui aposentar, mas não

como metalúrgico, só salário mínimo. Aí tenho que trabalhar aqui porque sou sem estudo e também por causa dos donos da CBT, que deixaram aquilo fechar [...] Como pôde? (Expedito, servente)

Em comum, dezessete entrevistados afirmaram que o maior problema de trabalhar na construção civil é a vulnerabilidade ocupacional e não somente o trabalho pesado, precário, ou a menor remuneração. O que preocupa o grupo analisado não é a precariedade das condições de trabalho na construção, mas sim a precarização do emprego em todos os setores produtivos. Diante disso, eles se sujeitam, constantemente, a situações nocivas e perigosas e reprimem qualquer tipo de descontentamento para não perder a vaga na empresa, ou a confiança do empreiteiro, ou um serviço. Trata-se, segundo Perrin (2004), apud Druck (2007), de mecanismos de controle social. São como "modos de subordinação" no novo contexto econômico do capitalismo flexível e mundializado, no qual os trabalhadores, por medo de perder o emprego e pela insegurança, se sujeitam ao "tempo produtivo". Antônio explica:

Quando comecei na construção, não engolia sapo. Sou calmo, mas se me desrespeitasse [...] Tenho meu valor. Eu pedia a conta e ia para outra construtora, tinha muita oportunidade. Mas agora é diferente. Você tem conta para pagar, então tem que respirar fundo, escutar coisas que te desagradam e continuar trabalhando. Até quando estou trabalhando por conta escuto desaforo. Vê a gente assim [mostra a roupa suja de pó de gesso] e acha que pode tratar igual cachorro. Não reclamo de mais nada. (Antônio, pedreiro)

Vivenciam também a ameaça constante de "não mais conseguir preencher os pré-requisitos", de serem excluídos de vez do mercado de trabalho:

Para ser sincero para a senhora, eu acho que daqui a pouco eu não vou servir mais nem para ser servente. Acho que, enquanto eu estiver com este empreiteiro, tenho emprego. O dia que ele parar e eu tiver que procurar emprego de novo, não acho. Não vou mais conseguir preencher os prérequisitos deles. [- Como assim, me explique melhor?] Velho para trabalhar em servico pesado, mal sei ler e fazer conta para ser ajudante de alguma coisa. Falo com a mulher que, se perder este emprego, vou ter que catar latinha na rua. Falo sério. (Paulo, servente). 
A angústia de um futuro incerto, diante do crescimento do desemprego, entremeia as falas dos trabalhadores. Conforme foi observado, à medida que a precariedade das relações de trabalho se torna um processo social presente em toda a sociedade, trabalhadores que, no passado, vivenciaram certo grau de direitos ou maiores oportunidades de trabalho assalariado percebem maior vulnerabilidade e fragilidade na construção civil, como os ex-metalúrgicos:

Acho que ninguém se sente estável! Hoje em dia, principalmente. Antes, tínhamos a sensação que se perdesse um emprego achava outro rapidamente. Também tinha os direitos, então sabia que podia pegar FGTS. Não me sinto estável. A instabilidade não vem só do lugar que você está, e sim da condição social que está no Brasil, econômica. De repente, você está seguro em determinada firma e esta firma vai embora, vai embora, e aí? Acho que é isso aí é difícil. Por isso que eu te falo: a gente tem que sempre aprender, procurar sempre fazer o que gosta, estudar. É importante estar sempre se reciclando. Olha meu caso: a Climax foi vendida, e, mesmo com curso superior, eu fui mandado embora. Custo, né? Na construção, eu não tenho estabilidade nenhuma. A minha estabilidade é a mulher. Ela é funcionária pública, isso sim, é garantido. Então, diminui o desespero, tenho tempo para arrumar outro serviço cada vez que acabo um. (Moisés, acabamento final).

O mesmo ocorre com os entrevistados mais jovens, quando são filhos de trabalhadores públicos, como Douglas e os irmãos Danilo e Francisco. Apesar de ser um dos poucos assalariados entrevistados, Douglas não considera o trabalho registrado sinônimo de estabilidade, pelo contrário:

Trabalho com carteira, mas isso não me faz sentir estável, é só “menos pior” do que estar jogado a sorte. Acho que minha mãe se sente estável, ela sim, eu não! [- Por que sua mãe se sente estável?] Ela é concursada, é enfermeira pública. O salário pode até atrasar, como acontecia quando éramos adolescentes [irmãos]. Lembro que atrasava, mas não falha, entende? Isso é estável. Agora, ter carteira não me dá estabilidade, só é "menos pior". Não sei se a firma vai quebrar, se amanhã ele vai continuar indo com a minha cara, ou se vai preferir outro cara. Meus negócios [criação de cavalos] dão segurança. Mas não ligaria de viver sem carteira se fosse para ter minha própria fazenda, meu próprio pasto, ai seria estável. (Douglas, montador)

Os irmãos Danilo e Francisco, filhos de um ferroviário aposentado e de uma dona de casa, mantiveram, por anos, a dupla jornada de trabalho em busca da estabilidade desfrutada, no passado, por sua família. Para eles, o trabalho registrado na metalúrgica poderia trazer a estabilidade que não tinham na construção. Entretanto, com o tempo, começaram a perceber que vivenciam maior instabilidade na metalúrgica do que trabalhando na construção.

Sempre tivemos de tudo. O pai era ferroviário e a mãe só cuidava da gente. Tudo do bom e do melhor. Depois que pai foi embora morar no Mato Grosso, a gente tinha que dar o mesmo para mãe. Ela cobrava sempre, tínhamos que ter um emprego certinho [registrado]. Mas não dá estabilidade! [-O que não te dá estabilidade, a construção ou a metalúrgica?] Não, os dois! Pode até ser que trabalhar com carteira seja mais seguro, mas não acho! Por isso, trabalhamos tanto! Não confio na metalúrgica, olha o que fizeram com meu irmão. Demissão em massa, entende? Tenho a sensação que sou o próximo. Na construção, também não sei se vamos ter serviço, só que, pelo menos, sempre tivemos. Mas, para mãe, o certo é trabalhar em fábrica. A gente conversa muito sobre o pai. Você olha para ele, e vê um senhor tranquilo, vive pescando. Acho que ele não tinha que se preocupar com o amanhã, se iam passar o facão? [risos] Meu irmão já foi [demitido]. Quem vai ser o próximo a sair da fábrica? (Francisco, pedreiro)

Muitos entrevistados não vislumbram mais a possibilidade de retornar ao mercado formal e, por outro lado, também não conseguem ver um futuro estável na construção, devido às grandes exigências de força física, bem como as oscilações constantes que esse setor historicamente sempre enfrentou. Segundo José:

Hoje a construção está boa, amanhã não sei. Tenho tempo de profissão e já peguei de tudo. Época que ninguém nem pintava a casa. Era difícil qualquer serviço. Hoje deu um 'bum'. O Lula melhorou o nosso lado. Olha isso [aponta para o condomínio residencial]. Há quanto tempo à senhora não vê isso? Está uma maravilha, mas e amanhã? Por isso, não posso dar o conforto que minha mulher merece. Ela tem que trabalhar. (José, pintor)

É marcante, no caso dos aposentados, a segurança que o benefício da aposentadoria acarretou na vida dos entrevistados e de suas famílias, mesmo quando precisam continuar trabalhando para aumentar a renda familiar. Percebem a aposentadoria como uma conquista pessoal e justa 
para uma vida dedicada desde a infância ao trabalho. Uma possibilidade de conseguir ter acesso a empréstimos, ao crediário e ao consumo.

Demorou, mas consegui! Minha aposentadoria vem todo mês. Aí dá para pensar em comprar um computador para os netos, um agrado para a mulher. A renda é curta, mas, com a aposentadoria, eles confiam mais na gente. Tá bem melhor agora. (Expedito, servente)

Na opinião de oito trabalhadores, a maior remuneração permitiria a adesão às formas de proteção e maior poder de consumo, trazendo, portanto, maior sensação de segurança. ${ }^{8}$

Se eu ganhasse bem, não ligaria ficar sem carteira, ou trabalhar por conta. Com um bom dinheiro, dava para pagar plano [saúde] e fazer um seguro para mim. [- Qual tipo de seguro?] É, de vida, aposentadoria, qualquer um que garantisse a mulher e os meninos. Mas é loucura ganhar mal e sem carteira. Não dá para dormir sossegado. (João Batista, acabamento final)

É possível afirmar que as estratégias familiares adotadas por alguns entrevistados aumentam a percepção de segurança, como no caso dos trabalhadores cujas esposas optaram por procurar um emprego registrado, ou conseguiram um emprego público estável e garantido. Porém uma grande maioria não percebe as tradicionais funções assistenciais exercidas pela família como fatores que tragam segurança, pois, como afirma Serapioni (2005), tais funções são pouco visíveis para os trabalhadores, na medida em que não resultam das relações trabalhistas, sendo caracterizadas por sua dimensão moral e afetiva.

Parte dos trabalhadores entrevistados

${ }^{8}$ Farias (2001, p.411) afirma que as noções de segurança e de proteção são diferentes. A proteção é um "elemento externo ao sujeito e possui, via de regra, uma materialidade própria; não é uma experiência subjetiva, mas sim um estado de coisas (leis, instituições, procedimentos, ações etc.)". Dessa forma, a noção de proteção relaciona-se à construção de mecanismos concretos que visam a atenuar ou eliminar as consequências do desenvolvimento capitalista, social e politicamente reconhecidas como negativas. Por outro lado, o autor explica que a sensação de segurança é "produto da mediação subjetiva operada pelo sujeito posto em contato com os eventos e processos que caracterizam o contexto específico em que ele está inserido, dentro do qual a existência de algum mecanismo de proteção constitui apenas um entre vários elementos. A segurança é uma experiência subjetiva que reflete a interação entre o conjunto de características particulares de cada sujeito (socioculturais, econômicas, psicológicas etc.) e um dado contexto". percebe a "precarização social” que, segundo Druck (2007, p.10), compreende uma “dupla institucionalização da instabilidade”, formada pela junção da “precarização econômica” (precarização da estrutura produtiva e da precarização salarial) com a "precarização da proteção social9" (transformação da legislação do trabalho e do sistema legislativo "fora do trabalho"). Como consequência, eles enfrentam cotidianamente a vulnerabilidade social e sofrem a "condição de insegurança e instabilidade misturadas com impotência, revolta e resignação.” (p.20).

Pode-se inferir, a partir da análise das trajetórias ocupacionais e da percepção dos trabalhadores, que, para a maioria do ex-metalúrgicos, trabalhar na construção significa perda de direitos e de garantias, bem como maior instabilidade de renda e menor capacidade de consumo. Trata-se de uma das últimas opções remanescentes diante da exclusão do mercado formal, e, por isso, muitos dos ex-metalúrgicos entrevistados não possuem o sentimento de pertencimento ao setor da construção civil.

Com exceção dos irmãos Danilo e Francisco e do entrevistado Moisés, deixar de ser metalúrgico denotou a perda da identidade profissional e a ruptura de projetos profissionais e (ou) pessoais, como o sonho "de se aposentar como um metalúrgico", ou de apenas continuar exercendo o ofício de metalúrgico, como narrado por Abraão. Segundo ele: "sou metalúrgico, só queria continuar sendo torneiro. Só queria isso. Não é certo ser demitido desta maneira! Tenho minha competência. Queria fazer o que sei, o que sou bom”. A transformação das trajetórias ocupacionais dos ex-metalúrgicos entrevistados representou ainda a perda das referências e do contato social com a categoria ocupacional da qual faziam parte. A esse respeito Expedito explica:

Enquanto trabalhei na CBT, tinha contato com os colegas de trabalho, era gostoso encontrar na rua. Hoje, tem o centro recreativo aquilo é uma maravilha. Meus meninos iam adorar. Já fomos

${ }^{9}$ Para Castel (2003), a proteção social é a condição para formar uma sociedade de semelhantes, o que podemos chamar de democracia. 
na colônia de férias, no litoral. Agora, que estou velho, não tenho mais contato com o pessoal e não dou conta de jogar bola com a molecada aqui dá obra. Eles são novos, o papo é outro. São divertidos, mas é diferente, entende? Fiquei sem lugar para passear! (Expedito, servente)

Por outro lado, para a maior parte dos trabalhadores de origem rural, que não vivenciaram em suas trajetórias o trabalho assalariado fabril, o trabalho na construção trouxe melhores condições financeiras e maior capacidade de consumo, a despeito da nocividade das condições de trabalho, e, por vezes, a menor precariedade, quando comparado com o período de trabalho no campo. Para eles, o trabalho urbano na construção vem permitindo, paulatinamente, o acúmulo de bens, bem como maior renda do que aquela que teriam se continuassem no campo. Existe a possibilidade de, quiçá, concretizarem futuramente o desejo de retornar para o meio rural, não mais na condição de empregado, mas como proprietário de um pedaço de terra, ou para cuidar da própria criação de animais.

Apenas para os entrevistados Douglas, Isaac e Mário, o trabalho na construção civil é visto como mais precário do que as atividades que realizavam no campo, no que se refere às condições de trabalho, ao ritmo de trabalho e à renda mensal. Para Douglas, o trabalho com a criação de animais era mais "agradável” e "tranquilo" do que na construção, enquanto, para Isaac, era mais "prazeroso" e "menos cansativo" trabalhar como tratorista, além da melhor remuneração. Na mesma direção, Mário explica que "trabalhar na construção não é a mesma coisa de trabalhar com a terra. Aqui [na obra] é muito puxado, é trabalho forte o tempo todo. Bem diferente de que ser caseiro. Eu fazia meu ritmo, não ficava trabalhando sob o sol forte e ainda morava naquela tranquilidade.”.

Dessa forma, pode-se afirmar que as sensações de insegurança e a percepção de precariedade dependem de múltiplos fatores. Não se pode concluir, por conseguinte, quais dos fatores apresentados exercem maior influência, uma vez que cada trabalhador vivencia de uma maneira sin- gular sua trajetória ocupacional e de vida.

Castel (2003) afirma que as sociedades modernas são construídas sobre o alicerce da insegurança, sentimento de estar à mercê de qualquer eventualidade. Para o autor, o que garante a proteção ${ }^{10}$ não é mais o grupo ao qual se pertence, mas a propriedade que se tem. É ela que garante a segurança diante dos imprevistos da existência.

Contudo, como foi observado, poucos entrevistados obtiveram, ao longo de suas trajetórias ocupacionais, oportunidades de acumular bens materiais para garantir sua proteção. Dessa forma, à medida que ocorre o aprofundamento da precariedade das condições trabalhistas e previdenciárias, bem como o recuo do papel regulador do mercado de trabalho exercido pelo Estado, um número maior de trabalhadores depara-se com a instabilidade de renda e de emprego. Para eles, as redes sociais informais tornam-se cada vez mais centrais, sendo, por vezes, a única ajuda concreta recebida em situações de crise e diante dos acasos sociais e naturais da existência.

\section{CONSIDERAÇÕES FINAIS}

Marcada historicamente por fases de expansão e retração, a construção de edificações vive hoje um período de crescimento do emprego formal. Assim como nas décadas anteriores, no entanto, a informalidade e flexibilidade dos contratos de trabalho permanecem expressivas nesse setor, a despeito dos incentivos por maior formalização do setor.

Acredita-se que, diante da grande capacidade de absorção de mão de obra, os órgãos governamentais fazem "vista grossa” para a precariedade existente, por vezes "naturalizando-a" como algo inerente à profissão ou "próprio" de um canteiro de obras. Por ser absolutamente fun-

${ }^{10}$ Castel (2003) diferencia a protecão em: proteção civil bens e pessoas em um estado de direito; proteção social riscos de doenças, acidentes, desemprego, incapacidade de trabalho devido à idade. 
cional à economia capitalista, a precariedade é tradicionalmente aceita pela sociedade e legitimada pelo próprio Estado.

O processo de precarização no setor não é um fenômeno novo, nem desconhecido pela literatura em sociologia do trabalho. Entretanto, à medida que a flexibilização e a precarização do trabalho ganham novas configurações, expandem-se para outros ramos produtivos e atingem as atividades centrais, a construção civil passa a absorver um novo perfil de trabalhador. Ele é novo não por ser flexível ou moderno, mas por englobar trabalhadores qualificados profissionalmente que se tornam obsoletos e, por isso, são descartados de vários segmentos do mercado de trabalho e absorvidos pela construção civil.

A crescente demanda por maior qualificação profissional e educação formal em todas as esferas da produção - do setor primário ao terciário - vem diminuindo as possibilidades de emprego formal para esse perfil de trabalhadores, ainda que, por ora, com baixa escolaridade (se comparados como os trabalhadores dos outros setores), porém qualificados profissionalmente e cada vez mais condenados à informalidade. Assim, dentro das novas configurações do trabalho, a construção de edificações deixa de ser, no caso de São Carlos, apenas uma opção para migrantes recémchegados de origem rural e para aposentados, ou um "bico" para os recém desempregados, uma vez que passa a ser uma opção de emprego e de renda para profissionais especializados marginalizados do mercado formal de trabalho, como os ex-metalúrgicos entrevistados.

O movimento de reestruturação ocorrido nas firmas de São Carlos deixou um legado enorme de desorganização nas trajetórias ocupacionais dos entrevistados. As principais implicações foram a perda da identidade profissional e, consequentemente, das identidades coletivas. Grande parte dos ex-metalúrgicos entrevistados não se identifica como operário da construção não possui sentimentos de pertencer ao setor nem mesmo entusiasmo coletivo.

Esse processo de reestruturação atingiu também o setor da construção, no qual, apesar de tradicionalmente precário, os discursos dos trabalhadores com mais tempo no setor mostram a intensificação da prática da subcontratação, estabelecida por meio de uma extensa rede de serviços contratados, repassados das empresas principais para empreiteiras e delas para organizações cada vez mais irregulares. Como consequência, mesmo entre aqueles cuja trajetória ocupacional ocorreu majoritariamente na construção, é possível identificar que a reestruturação trouxe maior insegurança nas relações trabalhistas, juntamente com o enfraquecimento da identidade coletiva. Os operários do setor passaram, progressivamente, a se sujeitar a modos de vida cada vez mais instáveis, não conseguindo mais se fixar numa posição ou categoria ocupacional como sujeitos permanentes.

Constatou-se que a institucionalização da instabilidade e da insegurança aumentou a vulnerabilidade dos entrevistados e os submeteu a uma série de constrangimentos como efetiva perda da qualificação preexistente, condições nocivas de trabalho, riscos constantes de acidente e contratos de trabalho precários ou "de boca". O contrato verbal prevalece para dezesseis dos entrevistados, sendo que, para minimizar a fragilidade desse tipo de relação, os trabalhadores comumente o associam questões relativas à honra ou à masculinidade dos contratantes.

A despeito da precariedade das relações de trabalho, metade dos entrevistados afirmou estar realizada profissionalmente com o trabalho desempenhado, enquanto a outra metade se percebe diminuída perante a sociedade pela falta de estudo, ou se identifica com as outras profissões exercidas anteriormente, como no caso dos ex-metalúrgicos entrevistados, vendo a construção como uma etapa passageira ou como a ultima opção que lhes restou.

Os resultados mostraram que, à medida que a flexibilização e a precarização do trabalho ganham novas configurações e se expandem para outros ramos produtivos, a construção de edificações, além de ser uma oportunidade de 
trabalho para jovens migrantes de origem rural, ou um "bico" para recém-desempregados, torna-se uma opção (ou falta de) de trabalho para operários fabris com baixa escolaridade, marginalizados do mercado formal de trabalho na cidade de São Carlos.

(Recebido para publicação em março de 2009) (Aceito em dezembro de 2009)

\section{REFERÊNCIAS}

BARROS, P.C.R; MENDES, A.M.B. Sofrimento psíquico no trabalho e estratégias defensivas dos operários terceirizados da construção civil. Psico-USF, Campinas,SP, v.8, n.1, p.6370, jan./jun., 2003.

BIHR, A. Da grande noite à alternativa. O movimento operário europeu em crise. Trad. Wanda Caldeira Brant. 2.ed. São Paulo: Editempo, 1998.

BRASIL. Minha casa, minha vida. Disponível em www.minhacasaminhavida.gov. br/index.html. Acesso em: 12 maio 2010

BREITBACH, A. C. Indústria da construção - a retomada. Indicadores Econômicos FEE. Porto Alegre,v.37, n.2, 2009.

CACCIAMALI, M.C. Globalização e processo de informalidade. Economia e Sociedade, Campinas,SP, n.14, p.153-174, jun, 2000.

CASTEL, R. L'insécurité sociale: qu'est-ce qu'être protégé ? Paris: Éd. du Seuil, 2003, 96 p.

COCKELL, F.F; PERTICARRARI, D. Retratos da informalidade: a fragilidade dos sistemas de proteção social em momentos de infortúnio. Ciência \& Saúde Coletiva (Oline), v.392, p.8. Disponível em: www.cienciaesaudecoletiva.com.br. Acesso em: 17 set., 2008.

Da enxada à colher de pedreiro: trajetórias de vulnerabilidade social na construção civil. 2008. $206 \mathrm{f}$. Tese (Doutorado em Engenharia de Produção). Universidade Federal de São Carlos. São Paulo, 2008.

DEJOURS, C. A loucura do trabalho. São Paulo: FTA/Oboré, 1987. 168p.

DIEESE. Boletim Trabalho e Construção, [S.l.], v.1, n.1, set, 2009.

Mercado de trabalho e rendimento no Brasil. Nota técnica 50, set 2007. Disponível em: www.dieese.org.br/ notatecnica/notatec50Pnad2007.pdf Acesso em: 22 mar. 2008.

DRUCK, G. A flexibilização e a precarização do trabalho na França e no Brasil: alguns elementos de comparação. In: SEMINÁRIO TEMÁTICO: TRABALHO E SINDICATO NA SOCIEDADE CONTEMPORÂNEA DA ANPOCS. Caxambu, MG, 2007.

FARIAS, L.O. Estratégias individuais de proteção à saúde: um estudo da adesão ao sistema de saúde suplementar. Ciência Saúde Coletiva, Rio de Janeiro, v.6, n.2, p.405-416, 2001.

FILGUEIRAS, C. H. Estructura de oportunidades y vulnerabilidad social: aproximaciones conceptuales recientes. In: SEMINÁRIO VULNERABILIDADE. Santiago do Chile: CEPAL, 2001.
FRANCO, E.M.A. Gestão do conhecimento na construção civil: uma aplicação dos mapas cognitivos na concepção ergonômica da tarefa de gerenciamento dos canteiros de obras. 2001. 252 f. Tese (Doutorado em Engenharia de Produção) - Programa de Pós-Graduação em Engenharia de Produção da Universidade Federal de Santa Catarina. Florianópolis, 2001.

Análise Ergonômica do posto de Mestre de Obras. 1995 $253 \mathrm{f}$. Dissertação (Mestrado em Engenharia de Produção) - Programa de Pós-Graduação em Engenharia de Produção da Universidade Federal de Santa Catarina. Florionópolis, 1995.

GITAHY, L. Inovação tecnológica, subcontratação e mercado de trabalho. São Paulo em Perspectiva. São Paulo, v. 8, n.1, 1994.

GONDIM, L.M.P.; LIMA, J.C. A pesquisa com artesanato intelectual. Considerações sobre método e bom senso. João Pessoa: Manufatura, 2002. 87p.

HONÓRIO, D.E. A qualidade de vida do operário da construção civil e sua importância na qualidade e produtividade em obras. 2002. 130 f. Dissertação (Mestrado em Engenharia de Produção) - Programa de Pós-Graduação em Engenharia de Produção, Universidade Federal de Santa Catarina. Florionópolis, 2002.

LAUTIER, B. Informalidade das relações de trabalho e cidadania na América Latina. Caderno CRH: revista do Centro de Recursos Humanos da UFBA, Salvador, n.18, p.5-48, 1993.

; PEREIRA, J.M. Representações sociais e construção do mercado de trabalho: empregadas domésticas e operários da construção civil na América Latina. Caderno CRH: revista do Centro de Recursos Humanos da UFBA, Salvador, v.7, n.21, p.125-151, jul/dez. 1994.

LIMA, J.C; SOARES, M.J.B. Trabalho flexível e o novo informal. Caderno CRH: revista do Centro de Recursos Humanos da UFBA, Salvador, v.15, n.37, p.163-180, jul-dez., 2002.

LIMA, I. S. Qualidade de vida no trabalho na construção de edificações: avaliação do nível de satisfação dos operários de empresas de pequeno porte. 1995, 215f. Tese (Doutorado em Engenharia) - Programa de Pós-Graduação em Engenharia da Universidade Federal de Santa Catarina. Florianópolis, 1995.

MANGAS, R.M.N. Acidentes fatais e desproteção social na construção civil no Rio de Janeiro. 2003, 73 f. Dissertação (Mestrado em Saúde Pública) - Programa de Pós Graduação em Saúde Pública da Fundação Oswaldo Cruz. Rio de Janeiro, 2003.

MATTOSO, J. O Brasil desempregado: como foram destruídos mais de 3 milhóes de empregos nos anos 90. São Paulo: Editora Fundação Perseu Abramo, 1999.

MELLO, L. C. B. B.; AMORIM, S. R. L. O subsetor de edificações da construção civil no Brasil: uma análise comparativa em relação à Unnião Europeia e aos Estados Unidos.

. O subsetor de edificações da construção civil no Brasil: uma análise comparativa em relação à União Europeia e aos Estados Unidos. Produção, Niteroi,RJ, v.19, n.2, p.388-399, 2009.

MINAYO, M.C.S. O desafio do conhecimento: pesquisa qualitativa em saúde. 8.ed. São Paulo: Hucitec; Rio de Janeiro: Abrasco, 2004

MORICE, A. Une legende à revoir: l'ouvrier du bâtiment brésilien dans feu ni lieu. Cahiers dês Sciences Humaines, Paris, v.29, n. 2-3, p. 349-371, 1993.

OLIVEIRA, R.P, IRIART, J.A.B. Representações do trabalho entre trabalhadores informais da construção civil. Psicologia em Estudo (oline), Natal, v.13, n.3, p. 437-445, 2008. "Tudo é arriscado": a representação do 
trabalho entre trabalhadores informais da construção civil. In: CONGRESSO NACIONAL SOBRE CONDICÕES E MEIO AMBIENTE DO TRABALHO NA INDUSTRIA DA CONSTRUÇÃO (CMATIC), 5, 23 a 26 de out., 2005, Olinda, Anais... Recife: Fundacentro, 2005.

RAMALHO, A.S. Combatendo a informalidade no setor da construção civil. Disponível em: www.horadopovo.com.br/ 2008/janeiro/2631-09-01-08/P4/pag4g.htm. Acesso em: 01 mar. 2008.

SANTOS, W.G. Cidadania e justiça: a política social na ordem brasileira. 2.ed. Rio de Janeiro: Campus, 1987.

SERAPIONI, M. O papel da família e das redes primárias na reestruturação das políticas sociais. Ciência \& Saúde Coletiva, Rio de Janeiro, v.10 (Sup), p. 243-253, 2005.

SERRA, S.M.B. Diretrizes para gestão dos subempreiteiros 2001. 379f. Tese (Doutorado em Engenharia da Construção Civil) - Programa de Pós-Graduação em Engenharia da Construção Civil da Escola politécnica da USP.
SINDUSCON-SP. Emprego na construção é recorde em janeiro. Disponível em: www.sindusconsp.com.br/ secoes.asp?categ=4\&subcateg=18. Acesso em: 04 maio 2010 .

Nível de emprego na construção civil registra alta recorde em 2007. Disponível em: www.sindusconsp.com.br/ msg.asp?id=1146. Acesso em: 04 jan. 2008.

SOUZA, N.H.B de. Trabalhadores pobres e cidadania: a experiência da exclusão e da rebeldia na construção civil. Uberlândia-MG: EDUFU, 2007. 258p.

SOUZA, U.; MELHADO, U.E.L.S. Subsídios para avaliação do custo da mão-de-obra na construção civil. São Paulo: Escola Politécnica da USP, 1991. 38p.

THEBAUD-MONY, A; DRUCK, G. Terceirização: a erosão dos direitos dos trabalhadores na França e no Brasil. In DRUCK, G; FRANCO, T. (Org) A perda da razão social do trabalho: terceirização e precarização. São Paulo: Boitempo, 2007, p.23-58. 
VERBAL CONTRACTS: the institutionalization of insecurity in construction

\section{Fernanda Flávia Cockell Daniel Perticarrari}

This paper examines the perception of construction workers in a context of social vulnerability, marked by the increasing precariousness of employment contracts. Twenty workers from São Carlos (Brazil) were interviewed, recovering their trajectories of work. Through qualitative analysis of the interviews, it was possible to verify the vulnerability and varied forms of employment contracts and remuneration. Despite the precariousness of labor relations, half of the workers claim to be professionally fulfilled in their occupation, while the other half perceive themselves to be diminished in society by the lack of schooling, or identify themselves with former occupations, seeing construction as a passing step or as the last option left to them.

KEywords: flexible labor, vulnerability, employment contracts, workers' perception, building construction.
CONTRAT ORAL: l'institutionnalisation de la précarité dans la construction civile

\section{Fernanda Flávia Cockell Daniel Perticarrari}

Cet article analyse la perception des travailleurs du bâtiment quant au contexte de la vulnérabilité sociale, marqué par la précarité croissante des contrats de travail. Nous avons interviewé vingt travailleurs de la ville de São Carlos (Brésil), et avons repris leurs trajectoires de travail. Grâce à une analyse qualitative de ces interviews, il a été possible de vérifier la vulnérabilité et les divers types de contrats de travail et de rémunération. Malgré la précarité existante dans les relations de travail, la moitié des travailleurs affirme être satisfaite professionnellement dans la fonction occupée, tandis que l'autre moitié se voit amoindrie dans la société par le manque d'études ou s'identifie avec d'autres professions exercées avant, considérant la construction comme une étape passagère ou comme la seule option qui leur restait.

Mots-CLÉS: flexibilité du travail, vulnérabilité, contrats de travail, perception ouvrière, construction d'immeubles.

Fernanda Flávia Cockell - Doutora e Mestre em Engenharia de Produção pela UFSCar. Pós-doutora em Sociologia pela UFSCar. Professora do Departamento de Saúde, Educação e Sociedade da Universidade Federal de São Paulo - Campus Baixada Santista. Coordena o Grupo de Pesquisa Trabalho, Saúde e Vulnerabilidade Social, desenvolvendo pesquisas na área de Saúde do Trabalhador, Vulnerabilidade Social, Redes Sociais, Trajetórias Ocupacionais, Saúde da Família e Promoção/Prevenção da Saúde. Suas mais recentes publicações, são: Da busca de seus direitos a efetivação: o caso dos agentes comunitários de saúde de Ribeirão Preto. In: Norma Valêncio; Antonio Carlos Witkoski; Elder de Paula. (Org.). Identidades e territorialidades. São Carlos: RiMa Editora e Edufscar, 2010, v. 1., p. 223-47; Retratos da informalidade: a fragilidade dos sistemas de proteção social em momentos de infortúnio. Revista Ciência \& Saúde Coletiva, v. 16, n. 3, 2011.

Daniel Perticarrari - Sociólogo. Mestre em Política Científica e Tecnológica pela UNICAMP. Doutor em Ciências Sociais pela UFSCar. Pós-Doutorando em Sociologia na Universidade Federal de São Carlos. Trabalha com temas relacionados à reestruturação produtiva, precarização do trabalho, gênero, cooperativas e educação superior. dperticarrari@yahoo.com.br 